\title{
PERBEDAAN TOTAL DISCRETIONARY ACCRUAL ANTARA BANK YANG MEMPEROLEH LABA DAN YANG MENGALAMI KERUGIAN DI INDONESIA
}

\author{
Ika Wulandari \\ Program Studi Akuntansi Fakultas Ekonomi Universitas Mercu Buana Yogyakarta \\ Email: ikawulandari@gmail.com
}

\begin{abstract}
Abstrak
Manajemen Laba (earning management) merupakan tindakan manajemen berupa campur tangan dalam proses penyusunan laporan keuangan dengan maksud untuk meningkatkan kesejahteraan baik secara individu maupun untuk perusahaan. Penelitian ini mengelompokkan sampel ke dalam dua kelompok, yaitu perusahaan perbankan yang mengalami kerugian dan perusahaan perbankan yang memperoleh keuntungan. Penelitian ini dimaksudkan untuk mengetahui indikasi terdapatnya praktek manajemen laba dan perbedaannya antara kedua kelompok bank tersebut. Berdasarkan hasil pengujian dengan menggunakan beberapa metode diperoleh hasil bahwa memang terdapat indikasi manajemen laba pada kedua kelompok bank yang diteliti. Diantara dua kelompok tersebut terdapat perbedaan discretionary accrual yang signifikan antara bank yang memperoleh laba dan bank yang mengalami kerugian, dimana bank yang memperoleh laba discretionary accrualnya lebih tinggi daripada pada bank yang mengalami kerugian.
\end{abstract}

Kata kunci : Earning Management (Manajemen Laba), Total Accrual, Discretionary accrual

\section{TOTAL DISCRETIONARY ACCRUAL DIFFERENCES BETWEEN BANKS GAINING PROFIT AND LOSS IN INDONESIA}

\author{
Ika Wulandari \\ Program Studi Akuntansi Fakultas Ekonomi Universitas Mercu Buana Yogyakarta \\ Email: ikawulandari@gmail.com
}

\begin{abstract}
Management Earnings (earnings management) is a management action in the form of interference in the process of preparing the financial statements with the intent to improve the welfare of both individuals and companies. This study grouped samples into two groups, namely the banking company which suffered losses and banking firms gain. This study aimed to determine the indication of the presence of earnings management and the difference between the two groups of banks. Based on the results of testing using several methods showed that indeed there are indications of earnings management in both groups of banks under study. Among these two groups there were significant differences in discretionary accruals between bank profits and bank losses, which the bank makes a profit of discretionary accrualnya higher than at banks that suffered losses.
\end{abstract}

Keyword : Earning Management, Total Accrual, Discretionary Accrual

PENDAHULUAN
Kegiatan perbankan dikatakan

berhasil apabila bank mampu menjaga 
keamanan dana masyarakat, mampu memberikan sumbangan yang berarti terhadap perkembangan ekonomi dan mampu meningkatkan kinerjanya. Pengukuran kinerja keuangan bank dapat dilihat dari rasio likuiditas, rentabilitas, maupun rasio kecukupan modal atau Capital Adequacy Ratio (CAR) serta besarnya Non Performing Loan (NPL) atau kredit bermasalah. Oleh karena itu otoritas moneter perlu melakukan pengawasan dan pengaturan terhadap kegiatan dalam perbankan salah satunya dengan melakukan pemeriksaan dan evaluasi laporan bank.

Salah satu laporan keuangan yang dikeluarkan bank adalah laporan laba rugi. Laporan ini digunakan sebagai parameter untuk mengukur kinerja manajer karena informasi laba atau rugi merupakan perhatian utama untuk menaksir pertanggung jawaban manajer. Jika perusahaan mampu menghasilkan laba atau meningkatkan laba yang cukup pada suatu periode, maka hal ini dapat dijadikan suatu ukuran berhasilnya kinerja manajer, begitu juga sebaliknya jika perusahaan mengalami kerugian atau penurunan laba. Terdapatnya kecenderungan untuk memperhatikan laba tersebut disadari oleh manajemen yang dapat mendorong timbulnya perilaku menyimpang yang salah satu bentuknya adalah earning management atau manajemen laba.

Menurut Scott (1997) manajemen laba didefinisikan sebagai tindakan manajer untuk untuk memilih kebijakan akuntansi dari suatu standar tertentu dengan tujuan memaksimalksan kesejahteraan atau nilai pasar perusahaan. Jadi manajemen laba merupakan tindakan manajemen untuk melaporkan laba perusahaan melalui laporan keuangan dengan cara memaksimumkan (meningkatkan) atau meminimumkan (mengurangi) laba yang dilaporkan pada suatu periode tertentu.

Manajemen laba dilakukan berdasar pada motivasi yang berbeda. Terdapat beberapa hal yang menyebabkan manajer termotivasi untuk melakukan praktek manajemen laba, seperti motivasi pasar modal, motivasi kontrak kompensasi manajemen, motivasi kontrak pinjaman, dan motivasi bonus. Bagi usaha perbankan sendiri, selain beberapa motivasi di atas manajemen laba dilakukan karena adanya motivasi manajer bank umum untuk mendapatkan penilaian yang baik atau paling tidak cukup baik dari laporan yang disajikan bank umum kepada Bank Indonesia setiap periodenya.

Untuk mendeteksi indikasi terdapat manajemen laba dalam suatu perusahaan dapat diketahui dari perhitungan total 
akrual yang diukur dengan total discretionary accruals. Discretionary accruals itu sendiri merupakan salah satu cara untuk mempengaruhi pelaporan laba yang sulit dideteksi melalui kebijakan akuntansi. Misalnya dengan cara menaikkan biaya depresiasi dan amortisasi, mencatat persediaan yang sudah usang, dan sebagainya. Tindakan manajemen laba selama tidak melanggar Standar Akuntansi yang ada dapat dilakukan untuk tujuan tertentu, misalnya ketika perusahaan akan melakukan penawaran saham perdana atau IPO, go public dan kegiatan lainnya. Dengan melakukan tindakan manajemen laba perusahaan harus siap menghadapi resiko yang akan terjadi, seperti penurunan kinerja keuangan dan laporan keuangan yang kurang accountable.

\section{PERUMUSAN MASALAH}

Berdasarkan latar belakang masalah tersebut di atas, maka yang menjadi pokok permasalahan dalam penelitian ini adalah;

a. Bagaimanakah indikasi manajemen laba dalam laporan keuangan perusahaan perbankan di Indonesia?

b. Bagaimanakah perbedaan antara total discretionary accruals antara bank laba dan bank rugi di Indonesia?

\section{TUJUAN PENELITIAN}

Adapun tujuan dari penelitian ini adalah :

a. Untuk mengetahui indikasi terdapatnya manajemen laba pada perusahaan perbankan di Indonesia.

b. Untuk mengetahui perbedaan total discretionary accruals pada perusahan perbankan yang memperoleh laba dan perusahaan perbankan yang memperoleh rugi.

\section{KAJIAN LITERATUR}

\section{Manajemen Laba}

Menurut Scott (1997) manajemen laba adalah;

"Tindakan manajer untuk memilih kebijakan akuntansi dari suatu standar tertentu dengan tujuan untuk memaksimalkan kesejahteraan dan atau nilai pasar perusahaan".

Dechow et.al (1996) mendefinisikan manajemen laba sebagai;

"Earning manipulation baik di dalam maupun di luar batas Generally Accepted Accounting Principles (GAAP)".

Dari sudut etika, Merchant (1994) mendefinisikan manajemen laba sebagai;

"Any action on the port of management which affects reported income and which provides no true economic advantage to the 
organization and may in fact in the long term be detrimental".

Sedangkan Ayres (1994) mengartikan manajemen laba sebagai;

The actions of manager that are intended to increase (decrease) current reported earnings of the unit for which the manager is responsibel without generating a cooresponding increase (decrease) in the long term economic profitability of the unit.

Jadi manajemen laba merupakan tindakan manajer berupa campur tangan dalam proses penyusunan laporan keuangan dengan maksud untuk meningkatkan kesejahteraannya secara individu maupun untuk meningkatkan nilai perusahaan.

Manajemen laba diduga muncul atau dilakukan oleh manajer atau para pembuat laporan keuangan dalam proses pelaporan keuangan suatu organisasi karena mereka mangharapkan suatu manfaat dari tindakan yang dilakukan.

Motivasi yang Mendorong Praktek Manajemen Laba

Manajemen laba dilakukan berdasar pada motivasi yang berbeda, yaitu (Yuskar et. al, 2003);

1. Motivasi pasar modal

2. Motivasi kontrak, yang terdiri dari Motivasi Kontrak
Kompensasi Manajemen dan

Motivasi Kontrak Pinjaman

3. Motivasi Pajak

Bagi usaha perbankan sendiri, selain beberapa motivasi di atas manajemen laba dilakukan karena adanya motivasi manajer bank umum untuk mendapatkan penilaian yang baik atau paling tidak cukup baik dari laporan yang disajikan bank umum kepada Bank Indonesia setiap periodenya.

\section{Bentuk Manajemen Laba}

Menurut Ayres (1994) manajemen laba dapat dilakukan melalui tiga cara, yaitu;

a. Manajemen Total Akrual

b. Penerapan Suatu Kebijaksanaan Akuntansi yang Wajib

c. Perubahan Metode Akuntansi Apabila manajer menggunakan pemilihan metode akuntansi, maka kebijakan ini dengan mudah diketahui oleh pemakai laporan keuangan, sedangkan apabila dengan mengendalikan akrual, maka kebijakan ini sulit terdeteksi oleh pemakai laporan keuangan. Oleh karena itu manajer cenderung melilih kebijakan rekayasa keuangan dengan mengendalikan transaksi akrual yaitu transaksi yang mempengaruhi arus kas (cash flow) (Friedlan, 1994).

\section{Total Akrual dan Discretionary Accruals}


Total akrual biasa digunakan sebagai proksi atas kebijakan akuntansi akrual. Akrual adalah suatu proses akuntansi untuk mengakui terjadinya peristiwa atau keadaan yang berhubungan dengan kas. Penggunaan akrual dilakukan dengan menggeser pendapatan masa depan menjadi menjadi pendapatan sekarang dan biaya sekarang menjadi biaya masa depan atau sebaliknya sehingga laba pada periode dilaporkan akan lebih tinggi atau lebih rendah dari seharusnya.

Jadi penggunaaan akrual ini dapat dilakukan dengan cara mempercepat atau menunda pengakuan pendapatan, menganggap sebagai ongkos (beban biaya) atau menanggap sebagai suatu investasi atas suatu biaya, contohnya; biaya perawatan aktiva tetap, kerugian atau keuntungan penjualan aktiva, serta perkiraan akuntansi lainnya seperti beban piutang ragu serta perubahan metode akuntansi. Beberapa penelitian sebelumnya menggunakan total akrual untuk memproksi tindakan yang mengarah pada manajemen laba atas suatu laporan keuangan.

Jones (1991) memisahkan total akrual menjadi dua yaitu akrual kebijakan (discretionary accruals) dan akrual bukan kebijakan (nondiscretionary accruals) sebagai alat untuk mengetahui apakan menejemen laba telah terjadi atau tidak.
Total akrual digunakan untuk mengukur manajemen laba pada tahap awal, selanjutnya mengkhususkannya pada discretionary accruals sebagai ukuran terhadap manajemen laba.

Discretionary accruals merupakan kebijakan akuntansi yang memberikan keleluasaan pada manajemen untuk menentukan jumlah transaksi akrual secara fleksibel. Kebijakan akuntansi akrual atau discretionary accruals (Scot, 1997) adalah suatu cara untuk mempengaruhi pelaporan laba yang sulit dideteksi melalui manipulasi kebijakan akuntansi yang berkaitan dengan akrual. Jadi discretionary accrual merupakan transaksi maupun metode akuntansi yang besarnya dipengaruhi oleh kebijakan manajemen.

Beberapa cara yang dilakukan untuk memanipulasi kebijakan akuntansi yang berkaitan dengan akrual adalah dengan menaikkan biaya amortisasi, menaikkan biaya depresiasi, mencatat kewajiban yang besar atas biaya garansi, potongan harga serta mencatat persediaan yang sudah usang. Apabila discretionary accrual suatu perusahaan cukup tinggi dibandingkan dengan rata-rata discretionary accrual pada umumnya, maka hal itu dapat digunakan sebagai indikasi terdapatnya manajemen laba pada perusahaan tersebut. Besarnya discretionary accrual juga dapat diketahui 
dengan cara membandingkan rata-rata discretionary accrual antara dua kelompok perusahaan. Jika salah satu kelompok mempunyai discretionary accrual lebih tinggi dengan perbedaan yang signifikan, maka hal itu merupakan indikasi terdapatnya manajemen laba pada kelompok perusahaan tersebut.

\section{Telaah Studi Sebelumnya}

Penelitian mengenai manajemen laba sudah banyak dilakukan, diantaranya adalah ;

a. Healy (1985) dalam penelitiannya menemukan bahwa manajer termotivasi untuk mengatur laba karena terdorong untuk memaksimalkan bonus yang dapat dia peroleh.

b. Sweeney (1994) meneliti tentang manajemen laba dalam kontrak perjanjian hutang. Perusahaan yang melalaikan kontrak hutang secara signifikan lebih banyak menggunakan kebijakan akuntansi dalam perusahannya.

c. Defond and Jimbalvo (1994) menguji manajemen laba dengan mengungkapkan pelanggaran perjanjian utang dan menemukan bukti bahwa penggunaan discretionary accruals untuk meningkatkan laporan laba dalam tahun sebelumnya untuk mengurangi tingkat pelanggaran perjanjian pada tahun berikutnya.

d. Gumanti (2000) menyimpulkan bahwa untuk perusahaan yang go public antara tahun 1995 dan 1997 menunjukkan bahwa manajemen laba pada pasar IPO di Indonesia terbukti ada khususnya pada periode dua tahun sebelum go public.

e. Harto (2001) menyimpulkan bahwa perusahaan yang melakukan right issue mengalami penurunan kinerja operasi, keuangan dan saham selama tiga tahun setelah penawaran.

f. Surifah (2001) menguji tentang indikasi terdapatnya manajemen laba pada perusahaan publik dan ditemukan bahwa terdapat indikasi unsur manajemen laba pada laporan keuangan perusahaan publik dan diketahui pula bahwa rata-rata nilai total akrual perusahaan yang mengalami kerugian jauh lebih tinggi secara signifikan dibandingkan dengan perusahaan yang memperoleh laba.

g. Agnes U. Widyaningdyah (2001) menguji analisis faktor yang berpengaruh terhadap earnings management pada perusahaan go public Indonesia. Dari penelitian 
tersebut diketahui bahwa dari beberapa faktor yang berpengaruh terhadap manajemen laba yaitu reputasi auditor, jumlah dewan direksi, leverage dan persentase saham yang ditawarkan, hanya leverage yang berpengaruh secara signifikan terhadap manajemen laba.

h. Sulistyanto (2002) menguji tentang manajemen laba pada saat Initial Public Offering merupakan indikasi sikap oportunistik manajemen. Dari penelitian tersebut dihasilkan bahwa jika manajer bersikap oportunis maka perusahaan issuer akan mengalami penurunan kinerja pasca penawaran sebagai akibat manajer melakukan rekayasa keuangan.

i. Yuskar. et.al (2003) menguji tentang manajemen laba dan pengecualian pajak pendapatan di Malaysia. Dari penelitian tersebut dihasilkan bahwa tidak ada bukti kuat yang mendukung terjadinya praktek manajemen laba pada tahun 1999 dengan pola memaksimumkan pelaporan laba yang termotivasi oleh dasar pengecualian pajak pendapatan pada tahun 1999 .
Dari beberapa penelitian tersebut dapat diketahui bahwa tidak semua perusahaan atau objek yang diteliti melakukan rekayasa keuangan. Pada perusahaan yang melakukan rekayasa keuangan dalam hal ini manajemen laba, manajer melakukan rekayasa keuntungan karena adanya motivasi tertentu yang tidak hanya didorong oleh manfaat pribadi tetapi juga untuk keperluan perusahaan.

\section{METODE}

\section{Populasi dan Sampel Penelitian}

Populasi penelitian ini adalah perusahaan perbankan di Indonesia yang meliputi bank umum swasta nasional devisa dan bank umum swasta nasional non devisa. Sedangkan sampel atau populasi bersyaratnya diambil secara berpasangan dimana bank yang mengalami kerugian berpasangan dengan bank yang memperoleh laba dengan jumlah sampel yang sama. Sampel penelitian diambil dari laporan keuangan bank dari tahun 2001 sampai dengan tahun 2005 pada bank yang mengalami rugi atau laba minimal selama tiga (3) tahun dari jangka waktu penelitian.

Berdasarkan hasil pengamatan yang dilakukan, maka diperoleh sampel atau populasi bersyarat sebagai berikut ; 
Tabel 1. Daftar Bank yang Mengalami Kerugian

\begin{tabular}{clcc}
\hline No & Sampel Bank Rugi & Keterangan & Tahun Kerugian \\
\hline 1. & Bank Century & Devisa & $2001,2002,2004$ \\
2. & Bank Windu Kentjana & Devisa & $2001,2002,2003$ \\
3. & Bank Swaguna & Non Devisa & $2002,2003,2005$ \\
4. & Bank Alfindo & Non Devisa & $2001,2003,2005$ \\
5. & Bank Ina Perdana & Non Devisa & $2001,2002,2003$ \\
6 & Bank Persyarikatan & Non Devisa & $2002,2004,2005$ \\
\hline
\end{tabular}

Tabel 2. Daftar Bank yang Memperoleh Laba

\begin{tabular}{clcc}
\hline No. & \multicolumn{1}{c}{ Sampel Bank Laba } & Keterangan & Tahun Laba \\
\hline 1. & Bank Mayapada & Devisa & $2001,2002,2004$ \\
2. & Bank IFI & Devisa & $2001,2002,2003$ \\
3. & Bank Bisnis Internasional & Non Devisa & $2002,2003,2005$ \\
4. & Bank Victoria & Non Devisa & $2001,2003,2005$ \\
5. & Bank Eksekutif Internasional & Non Devisa & $2001,2002,2003$ \\
6. & Bank Akita & Non Devisa & $2002,2004,2005$ \\
\hline
\end{tabular}

(Sumber data : www.bi.go.id)

Data

Data yang digunakan dalam penelitian ini adalah data sekunder berupa laporan keuangan perusahaan perbankan yang diambil dari situs resmi www.bi.go.id selama tiga (3) tahun dari jangka waktu penelitian lima (5) tahun dari tahun 2001 sampai tahun 2005.

\section{Cara Pengumpulan Data}

Metode pengumpulan data adalah dokumentasi, yaitu metode pengumpulan data yang dilakukan dengan membuat salinan dengan cara menggandakan arsip dan catatan perusahaan yang diperoleh dari situs resmi www.bi.go.id.

\section{Metode Analisis Data}

Model yang digunakan untuk menghitung discretionary accrual dalam penelitian ini menggunakan dua metode yaitu ;

\section{a. Rata-rata Total Akrual sebagai proksi Discretionary Accrual}

Langkah yang digunakan untuk menghitung discretionary accrual adalah sebagai berikut;

1. Menghitung Total Akrual

Untuk menghitung Total Akrual digunakan formula sebagai berikut (Jones, 1991);

$$
\begin{aligned}
\mathrm{TA}_{\mathrm{it}}= & \left(\Delta \mathrm{CA}_{\mathrm{it}}-\Delta \mathrm{CL}_{\mathrm{it}}-\Delta \mathrm{Cash}_{\mathrm{it}}+\Delta\right. \\
& \left.\mathrm{STD}_{\mathrm{it}}-\mathrm{Dep}_{\mathrm{it}}\right) / \mathrm{A}_{\mathrm{it}-1}
\end{aligned}
$$

Dimana;

$\Delta \mathrm{CA}_{\mathrm{it}}$ : Perubahan aktiva lancar pada perusahaan i pada tahun ke $\mathrm{t}$

$\Delta \mathrm{CL}_{\mathrm{it}}$ : Perubahan Utang Lancar perusahaan i pada tahun ke $\mathrm{t}$

$\Delta$ Cash $_{\mathrm{it}}$ : Perubahan kas dan ekuivalen kas pada perusahaan $\mathrm{i}$ tahun ke $\mathrm{t}$

$\Delta \mathrm{STD}_{\text {it }}$ :Perubahan utang jangka panjang yang akan segera jatuh 
tempo dalam waktu satu tahun pada perusahaan i tahun ke $\mathrm{t}$

Dep $_{\text {it }} \quad$ : Depresiasi dan Amortisasi pada perusahaan i pada tahun ke $\mathrm{t}$

$\mathrm{A}_{\mathrm{it}-1} \quad$ : Total aktiva satu (1) tahun sebelum $t$

2. Uji Statistik Independent Sample T Test

Pada model ini discretionary accrual diperoleh dari rata-rata Total Akrual pada perusahaan yang diteliti dengan menggunakan uji $\mathrm{t}$ ( independent sample t test). Untuk mengetahui apakah pada perusahaan yang diteliti terindikasi manajemen laba maka dapat dilihat dari tingkat signifikansi yang diperoleh.

Apabila rata-rata Total Akrual (discretionary accrual) cukup tinggi dibandingkan discretionary accrual pada umumnya hal tersebut dapat digunakan sebagai indikasi terdapatnya manajemen laba pada perusahaan tersebut. Untuk mengetahui apakah pada perusahaan yang diteliti terdapat indikasi manajemen laba dapat diketahui dengan membandingkan rata-rata Total Akrual pada dua kelompok perusahaan. Jika salah satu kelompok mempunyai discretionary accrual yang lebih tinggi dengan perbedaan yang signifikan, maka hal tersebut merupakan indikasi terdapatnya manajemen laba (earning management).

Jika probabilitas $<0.05$, maka Ho1 ditolak
Jika probabilitas $>0.05$, maka Hol diterima

Formula Hipotesis;

Ho1 : Tidak terdapat perbedaan antara rata-rata Total Akrual (discretionary accrual) antara bank laba dan bank rugi

Hi1 : Terdapat perbedaan antara rata-rata Total Akrual (discretionary accrual) antara bank laba dan bank rugi

\section{b. Industry Adjusted Model}

Model ini menggunakan ukuran tendensi sentral dalam aplikasinya yaitu mean atau median. Langkah yang dilakukan dalam metode ini adalah ;

1. Menghitung

Discretionary accrual

Pada model ini formula yang digunakan untuk menghitung discretionary accrual adalah sebagai berikut;

$\mathrm{DA}_{\mathrm{it}}=\mathrm{TA}_{\mathrm{it}}-\mathrm{NDA}_{\mathrm{it}}$ Dimana;

DA $_{\text {it }}$ : Discretionary accrual

perusahaan i pada tahun ke $\mathrm{t}$

$\mathrm{TA}_{\text {it }} \quad$ : Total Accrual perusahaan i pada tahun ke $\mathrm{t}$

$\mathrm{NDA}_{\text {it }}$ : Non Discretionary accrual perusahaan i pada tahun ke $\mathrm{t}$

Sedangkan untuk menghitung Non Discretionary Accrual (NDA) dengan menggunakan Industry Adjusted Model dapat dirumuskan sebagai berikut;

$\mathrm{NDA}_{i t}=$ Mean atau Median $\left(\mathrm{TA}_{\mathrm{it}(\mathrm{BLR})}\right)$ 
Dimana :

$\mathrm{NDA}_{\mathrm{it}}$ : Non Discretionary accrual perusahaan I pada tahun ke $\mathrm{t}$

$\mathrm{TA}_{\text {it(BLR): }}$ Total Accrual perusahaan baik bank laba maupun rugi pada tahun ke t

\section{Uji Statistik}

Pengujian ini dilakukan untuk membuktikan bahwa pada tahun yang diamati telah terindikasi adanya tindakan manajemen laba pada variabel discretionary accrual yang diuji dengan menggunakan Uji T (independent sample t test). Formula hipotesis pada metode ini adalah;

Ho2 :Berarti tidak terdapat indikasi manajemen laba pada perusahaan perbankan yang diteliti.

Hi2 : Berarti terdapat indikasi manajemen laba pada perusahaan perbankan yang diteliti.

Apabila t-hitung $<(+)$ t-tabel, atau $\mathrm{t}$ hitung $>(-)$ t tabel, maka Ho2 diterima atau apabila t-hitung $>(+)$ t-tabel atau $t$ hitung $<(-)$ t tabel, maka Ho2 ditolak

\section{Mengambil keputusan berdasar probabilitas}

Ho3 : Berarti tidak ada perbedaan discretionary accrual antara bank yang memperoleh laba dan bank yang mengalami kerugian
Hi3 : Berarti terdapat perbedaan antara discretionary accrual antara bank yang memperoleh laba dan bank yang mengalami kerugian

Jika probabilitas $>0,05$ maka Ho3 diterima atau jika probabilitas $<0,05$ maka Ho3 ditolak

\section{HASIL DAN PEMBAHASAN}

Pengolahan dan analisis data dilakukan dengan menggunakan metode rata-rata total akrual sebagai proksi discretionary accrual dan Industry Adjusted Model yang meliputi beberapa tahapan, yaitu; (1) Menghitung Total Akrual (2) Menghitung discretionary accrual (3) Menganalisis data dengan menggunakan bantuan program SPSS yaitu independent sample $t$ test Mengambil kesimpulan dari hasil yang diperoleh.

\section{Analisis Data}

a. Pengujian dengan Metode Ratarata Total Akrual

Penelitian ini ingin menguji kemungkinan terdapatnya indikasi manajemen laba pada perusahaan perbankan dengan menguji dan membandingkan Total Akrual perusahaan perbankan yang mengalami kerugian dengan perusahaan perbankan yang mengalami laba. Rata-rata Total Akrual 
dipergunakan sebagai proksi kebijakan akuntansi akrual (discretionary accrual)

Berdasarkan hasil uji independent sample $t$ test dengan menggunakan tingkat kepercayaan $95 \%$ atau $\alpha=5 \%, \mathrm{df}=34$ dengan uji dua sisi diperoleh hasil sebagai berkut;

Tabel 3. Hasil Uji dengan Independent Sample T-Test

\begin{tabular}{ccccc}
\hline Variabel & Numb. of cases & Mean & Sign & Mean Difference \\
\hline Rata-rata TA Bank Rugi (DA) & 18 & -0.1545 & & \\
Rata-rata TA Bank Laba (DA) & 18 & 0.0634 & 0.002 & -0.2179 \\
\hline
\end{tabular}

Sumber : Data diolah

Keterangan ;

TA : Total Accrual

DA : Discretionary Accrual

Berdasarkan Tabel 3 tersebut

didapat hasil bahwa diperoleh tingkat signifikansi sebesar 0,002 yang nilainya lebih kecil daripada 0,05. Oleh karena probabilitas $<0.05$, maka Ho1 ditolak atau Hil diterima, yang berarti antara rata-rata Total Akrual (discretionary accrual) antara bank laba dan bank rugi adalah benar-benar berbeda, dalam arti bank laba mempunyai rata-rata Total Akrual yang lebih tinggi daripada bank rugi. Terjadinya perbedaan yang signifikan antara dua kelompok yang diteliti ini juga mengindikasikan terjadinya praktek manajemen laba (earning management) pada kedua kelompok perusahaan tersebut.

Dari Tabel 3 tersebut juga dapat diketahui bahwa rata-rata Total Akrual (discretionary accrual) perusahaan perbankan yang mengalami kerugian menunjukkan angka negatif sebesar 0,1545 hal ini mengindikasikan terdapatnya manajemen laba dengan cara menurunkan tingkat laba yang diperoleh, meskipun indikasinya terlihat masih lemah. Sedangkan pada perusahaan perbankan yang memperoleh laba menunjukkan rata-rata Total Akrual (discretionary accrual) yang positif, yaitu sebesar 0,0634, hal ini mengindikasikan terdapatnya unsur manajemen laba dengan cara meningkatkan angka laba.

Jika dilihat dari perbedaan antara kedua kelompok bank tersebut, maka terdapat perbedaan yang signifikan antara perusahaan perbankan yang mengalami kerugian dan perusahaan perbankan yang mengalami laba. Perusahaan yang mengalami laba nilai rata-rata Total Akrual (discretionary accrual) nya lebih tinggi daripada rata-rata Total Akrual (discretionary accrual) bank yang mengalami kerugian dengan perbedaan (mean difference) sebesar $-0,2179$.

\section{b. Pengujian dengan Menggunakan Industry Adjusted Model}

Berdasarkan hasil pengolahan menggunakan uji statistik independent 
sampel t test dengan menggunakan tingkat kepercayaan $95 \%$ atau $\alpha=5 \%$, df $=34$ dengan uji dua sisi diperoleh hasil sebagai berkut;

Tabel 4. Uji t

\begin{tabular}{cccc}
\hline Variabel & T Hitung & T Tabel & Signifikansi \\
\hline Discretionary accrual & -3.965 & -2.021 & 0.000 \\
\hline
\end{tabular}

Sumber : Data diolah

Berdasarkan tabel 4 tersebut di atas, didapatkan t hitung sebesar -3.965 yang lebih kecil daripada t tabel sebesar -2.021. Oleh karena t hitung lebih kecil daripada $t$ tabel yaitu $-3.965<-2.021$, maka $\mathrm{Ho} 2$ ditolak dan Hi2 diterima, yang berarti pada perusahaan perbankan baik yang menderita rugi maupun yang memperoleh laba terindikasi melakukan tindakan manajemen laba.

Gambar 1. Daerah Penerimaan atau Penolakah Ho Atas Indikasi Manajemen Laba

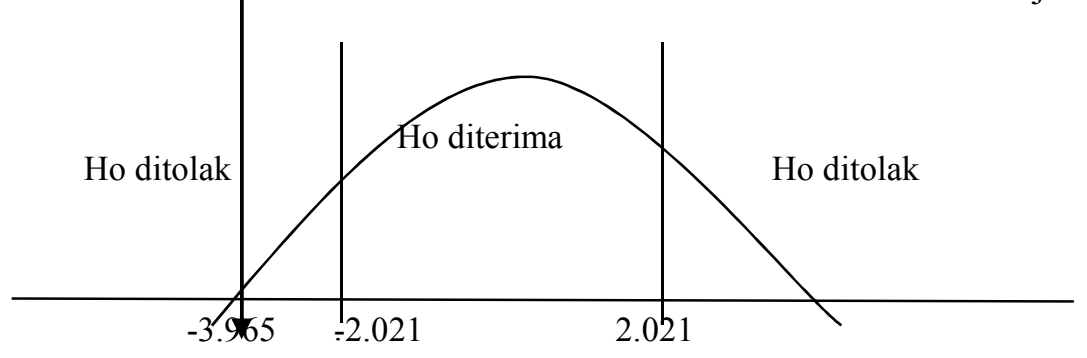

Berdasarkan tingkat signifikansi yang diperoleh sebesar 0.000 yang lebih kecil daripada 0.05 , maka $\mathrm{H}_{03}$ ditolak dan $\mathrm{H}_{\mathrm{i} 3}$ diterima, yang berarti bahwa total discretionary accrual antara bank laba dan bank rugi berbeda, dalam arti bank laba mempunyai total discretionary accrual yang lebih tinggi daripada total accrual.

Hasil pengujian untuk mengetahui rata-rata total discretionary accrual dan tingkat perbedaannya disajikan dalam Tabel 5;

Tabel 5. Hasil Uji dengan Independent Sample T-Test

\begin{tabular}{ccccc}
\hline Variabel & Numb. Of cases & Mean & SD & Mean Difference \\
\hline Discr. Accrual Bank Rugi & 18 & -0.1000 & 0.17638 & \\
Disc. Accrual Bank Laba & 18 & 0.1000 & 0.12135 & -0.2001 \\
\hline Sumber. Data diolah & &
\end{tabular}

Sumber : Data diolah

Berdasarkan Tabel 5 terlihat bahwa discretionary accrual bank yang memperoleh rugi menunjukkan angka negatif sebesar -0.1000 yang berarti bahwa bank yang mengalami kerugian melakukan praktek manajemen laba dengan menurunkan tingkat labanya. Sedangkan pada bank yang memperoleh laba terlihat bahwa angka yang diperoleh adalah positif sebesar 0.1000 . Hal ini 
menunjukkan bahwa pada bank laba terdapat indikasi manajemen laba dengan cara menaikkan labanya.

Jika dilihat dari perbedaan antara kedua kelompok bank tersebut, maka terdapat perbedaan yang signifikan dengan tingkat signifikansi 0.05 antara perusahaan yang laba dan yang rugi. Perusahaan yang memperoleh laba lebih tinggi nilai total discretionary accrualnya daripada perusahaan perbankan yang memperoleh laba dengan perbedaan sebesar -0.2001 .

\section{KESIMPULAN}

Dari hasil analisis data dapat disimpulkan bahwa memang terdapat indikasi manajemen laba pada perusahaan perbankan di Indonesia walaupun indikasinya tidak begitu kuat.

Dengan menggunakan metode ratarata total akrual yang digunakan sebagai proksi kebijakan akuntansi akrual (discretionary accrual) diperoleh tingkat signifikansi sebesar 0,002 yang lebih kecil daripada 0,05 . Oleh karena probabilitas lebih kecil daripada 0,05 maka hal ini membuktikan bahwa pada perusahaan perbankan yang diteliti memang terdapat perbedaan discretionary accrual yang signifikan antara bank yang memperoleh laba dan bank yang mengalami kerugian. Hal tersebut mengindikasikan terjadinya praktek manajemen laba pada kedua belas perusahaan perbankan yang diteliti. Pada bank yang mengalami kerugian indikasi laba dilakukan dengan cara menurunkan laba yang terlihat dari hasil mean sebesar $-0,1545$ dan pada perusahaan perbankan yang memperoleh laba dengan cara menaikkan tingkat laba yang terlihat dari hasil mean sebesar 0,0634. Perbedaan antara rata-rata total akrual antara bank yang memperoleh laba dan rugi adalah sebesar -0,2179, dimana bank yang memperoleh laba mempunyai rata-rata total akrual yang lebih tinggi daripada bank yang mengalami kerugian.

Dengan Industry Adjusted Model hasil yang diperoleh tidak jauh berbeda, dimana didapatkan $\mathrm{t}$ hitung yang lebih kecil daripada (-) t tabel, yaitu $-3,965<$ 0,2021 yang mengindikasikan terdapatnya praktek manajemen laba pada perusahaan perbankan. Rata-rata discretionary accrual bank yang mngalami kerugian menunjukkan angka negatif sebesar 0,1000 yang mengindikasikan bahwa manajemen laba dilakukan dengan cara menurunkan tingkat laba, sedangkan pada bank yang memperoleh laba rata-rata discretionary accrual menunjukkan angka positif sebesar 0,1000 yang berarti bahwa praktek manajemen laba dilakukan dengan cara menaikkan angka laba. Dengan tingkat signifikansi sebesar 0,000 yang lebih kecil dari 0,05 jelas terlihat bahwa memang terdapat perbedaan yang 
nyata antara discretionary accrual pada bank yang memperoleh laba dan bank yang mengalami kerugian dengan tingkat perbedaan sebesar $-0,2001$.

\section{DAFTAR PUSTAKA}

Anthony, Robert and Vijay Govindarajan (1995). Management Control Systems. Irwin : Homewood. Illionis

Ayres. F. F. (1986) “ Characteristic of Firm Electing Early Adoption of SFAS 52", Journal of Accounting and Economics, 58 : 143-158

Ayres F. F (1994) “Perception of Earning Quality : What Man Agers Need to Know", Management Accounting , p 27-29

Belkaoui, Ahmad R. (1993). Accounting Theory, Cambridge : The University Press

Dechow, Patricia, Richard G. Sloan and Amy P. Sweeney. (1995). "Deteching Earning Management". Accounting Review. April, p. 193-225.

Dechow, Patricia, Richard G. Sloan and Amy. P. Sweeney. (1996), “" Causes and Consequences of Earning Manipulation : An Analysis of Firm Subject to Enforcement Actions by the SEC', Contemporary ccounting Research 13, 1-36

Defond, M. L, and J. Jimbalvo. (1994). "Debt Covenant Violations and Manipulations of Accruals". Journal of Accounting and Economics, Vol. 17, p: 145-176

Friedlan, J (1994), “Accounting Choices by Issuers of Initial Public
Offering". Contemporary Accounting Research. Summer

Gumanti. (2000). “ Earning Management : Suatu Telaah Pustaka". Jurnal Akuntansi dan Keuangan. Vol. 02. No. 02. November 2000. hal. 104-115

Harto, Puji. (2001). “ Analisis Kinerja Perusahaan yang Melakukan Right Issue di Indonesia. Simposium Nasional Akuntansi IV.

Healy Paul M. (1985). "The Effect of Bonus Schemer on Accounting Discretions". Journal of Accounting and Economics Vol. $7: 85-107$

Healy Paul M dan Palepu Krisna (1993). “ The Effect of Firms, Financial Disclosure Strategies on Stock Prices". Accounting Horizon. Vol. 07. No. 1. Maret. P. 1-11

Jones, Jennifers (1991), “Earnings Management During Import Relief Investigation". Journal of Accounting Research 29 Autumn. p. 193-228.

Merchant, R. A (1994), “ The Ethics of Managing Earnings an Empirical Investigation", Journal of Accounting and Public Policy, 13 : 79-94

Mustofa, Hamim. (2004). Basis Akuntansi Pemerintahan.Jakarta.Direktorat Jenderal Perbendaharaan

Santoso, S (2002). SPSS Ver. 10. Jakarta. Percetakan PT. Gramedia

Scot, William R. (1997). " Financial Accounting Theory". New Jersey Prentice-Hall International, A Simon Schuster Company. Upper Suddle River. p 38-39 
Sinungan M. (2000). Manajemen Dana Bank. Jakarta. Sinar Grafika Offset

Sugiri, Slamet (1998). "Earning Management : Teori, Model, dan Bukti Empiris". Telaah, hal $1-18$

Sulistyanto, H. Sri. (2002). " Analisis Manajemen Laba pada Saat Initial Public Offering". Jurnal of Finance. Vol. XLVI .p.1

Sulistyanto, H. Sri, dan Maniek S. Prapti. (2003). " Stock Option : Benarkah Mendorong Eksekutif Oportunis?". Jurnal Akuntansi Bisnis. Vol. 1. No. 01. Maret.

Surifah. (2001). "Studi tentang Indikasi Unsur Manajemen Laba pada Laporan Keuangan Perusahaan Publik di Indonesia". Jurnal Akuntansi dan Auditing. Vo. 5. No. 1. Juni. Hal. 81-99.

Sutrisno. (2001). “ Studi Analitikal Pengaruh Bentuk Manajemen Laba (Earning Management) terhadap Hubungan Antara Return Laba". Lintasan Ekonomi. Vol. 8. No. 02. Juli 2001.p. 75-87
Sweeney, A. (1994). "Debt-Covenant Violation and Managers Accounting Responses". Journal of Accounting \& Economic. P281-388

Riyadi, Slamet. (2003). Banking Assets and Liability Management. Jakarta.FE Universitas Indonesia

Tunggal, A. W. (1994). Dasar-dasar Akuntansi Bank. Jakarta. PT Rineka Cipta.

Widyaningdyah. (2001). “ Analisis Faktor yang Berpengaruh terhadap Earnings Management pada Perusahaan Go Public di Indonesia". Jurnal Akuntansi dan Keuangan. Vol 03. No. 02. November 2001. hal. 89-101

www.bi.go.id

Yuskar,et.al. (2003). "Manajemen Pendapatan dan Pengecualian Pajak Pendapatan di Malaysia". Jurnal Akuntansi dan Keuangan. Vol 05. No. 02. November 2003. p. 91-109 